\title{
Archipel
}

ARCHIPEL Études interdisciplinaires sur le monde insulindien

$97 \mid 2019$

Varia

Festival Budaya dan Seminar Internasional La Galigo III, 17 to 23 December 2018, Watansoppeng, Sulawesi Selatan, Indonesia

Campbell Macknight and Muhlis Hadrawi

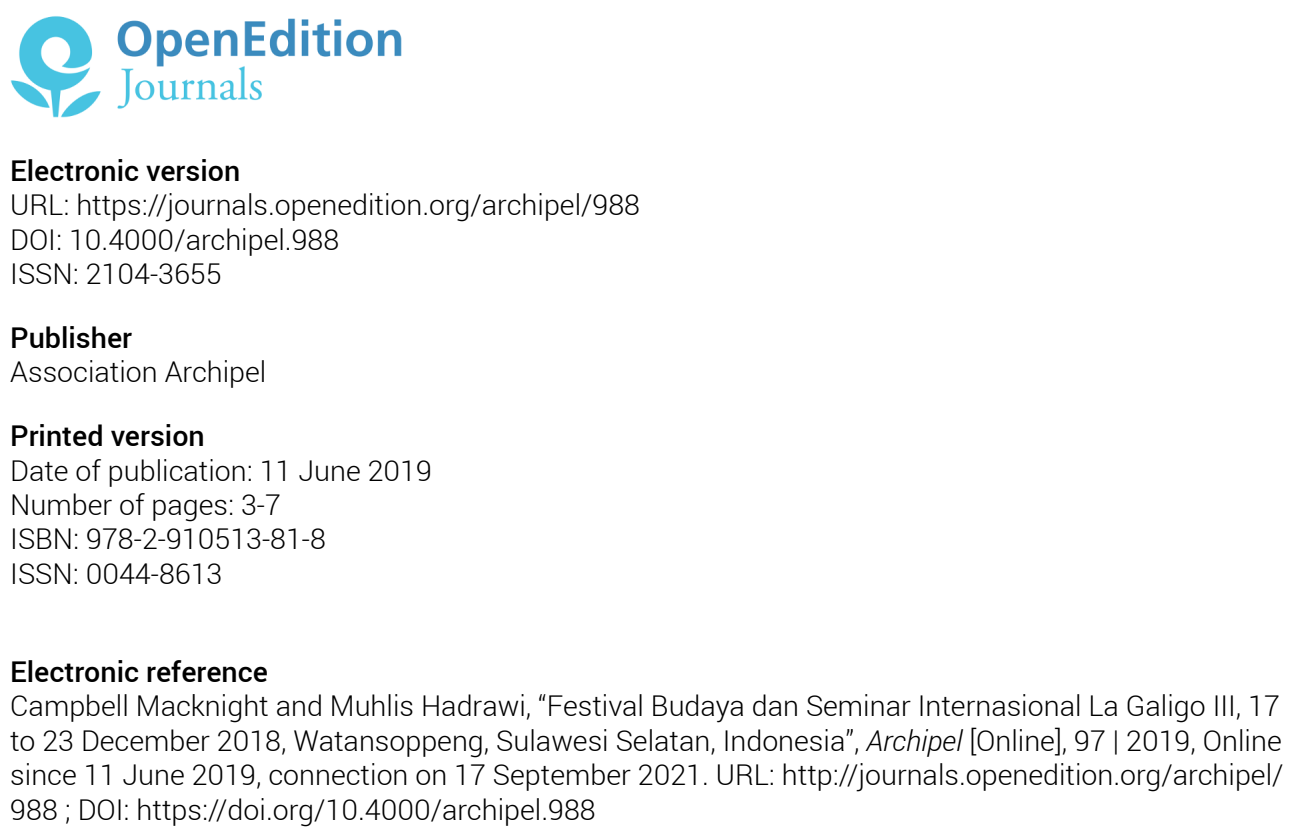

Association Archipel 


\section{ÉCHOS DE LA RECHERCHE}

\section{Festival Budaya dan Seminar Internasional La Galigo III, 17 to 23 December 2018, Watansoppeng, Sulawesi Selatan, Indonesia}

This was the third in a series of cultural festivals and academic seminars in South Sulawesi named after the great cycle of stories known as La Galigo. Overall management of event arose from cooperation between the kabupaten government in Soppeng and Universitas Hasanuddin in Makassar, with the academic program arranged by the Departemen Sastra Daerah, Fakultas Ilmu Budaya of the university.

The first of these events at Barru in 2002 celebrated the fact that Colli'pujié, the great expert in La Galigo literature and informant of B.F. Matthes in the nineteenth century, had been a local ruler near Barru (Macknight 2003). The second at Masamba in 2003 marked the importance of Luwu in the stories and was held in at a time of some tension between traditional ideas and resurgent Islamist values (Robinson 2011). This latest event, coming after a substantial delay, marked growing interest in local cultural matters and reflected the role of Soppeng as one of the central Bugis states in the past and today a thriving kabupaten.

Each of these events was made possible by the devolution of power and money to the kabupaten level over the last twenty years. Held outside the major city of Makassar, their dual nature combines several interests. On the one hand, they bring visitors from elsewhere in South Sulawesi and the nation, as well as some international scholars, to a local audience, reinforcing a sense of local significance, while on the other hand, they display the local cultural riches to that wider audience, as well as to the locals themselves. Soppeng was in a festive mode for the week and the bupati, H. A. Kaswadi Razak, provided strong leadership and expansive hospitality. 
The program began with a parade of local groups and others from neighbouring areas, all in splendid costumes, passing a reviewing stand in front of the main mosque. This led on to an elaborate ceremony of welcome in the park at Ompo, on the fringe of the town. A great crowd had assembled and, after the usual speeches, the display area in front of the official dais was taken over by massed dancers and, after them, by an orchestra of local children playing traditional instruments. Booths from each sub-district provided a range of refreshments. Each evening over the following week, a program of cultural events was presented in the central town square. All kinds of traditional and contemporary music and dance were featured, including several dramatic presentations of the La Galigo stories which showed the influence of the famous opera production shown around the world in recent years (Pelras 2005).

The quality and variety of these presentations bore witness to the cultural vigour of contemporary Bugis society, especially among young people who participated with obvious enjoyment in traditional cultural forms, as well as appreciating modern musical items. A notable instance of local pride is the use of the Bugis lontara' script to write both Bugis and Indonesian; this is much more widespread in signs than it once was. It also now commonly appears on clothing and other fabrics. While some expressions of this enthusiasm for tradition can seem a little artificial, and challenges from conservative Islam have not wholly gone away, there can be no mistaking the new assertion of Bugis identity which acknowledges, among other things, the memory of the former kingdoms, together with the significance of their symbolic regalia, and a role for the bissu or shamans. The name of La Galigo has come to connote much of this identity.

The seminar element in the event was held over two days in the large meeting hall beside the town square. An audience consistently numbering several hundred showed the interest, or at least curiosity, of local people in their heritage. While contributions from scholars associated with Universitas Hasanuddin were prominent, a meeting such as this provides space for interaction with those from other institutions. Outside the hall, a wide range of recent books of interest was for sale and a display of local keris, badik and other knives and weapons demonstrated an important aspect of traditional material culture.

Our knowledge of the La Galigo literature has been transformed in recent years by the availability of major publications. Most obviously, Yayasan Obor has published transcriptions and Indonesian translations of three of the twelve parts of the famous NBG 188 manuscript in Leiden which was Colli'pujié's attempt to provide Matthes with a copy of the "whole" tradition (Salim and others 2017). Moreover, all twelve parts of the manuscript itself, inscribed by UNESCO on the Memory of the World register, have been digitised by 
the Leiden University library and are available for free download. Significant digitised material is also freely available from the Staatsbibliothek's Schoemann collection in Berlin. Other lengthy transcriptions and translations can be found in the published theses of the late Fachruddin Ambo Enre (Ritumpanna Wélenrénngé 1999), Nurhayati Rahman (Cinta, Laut dan Kekuasan 2006) and Andi Muhammad Akhmar (Islamisasi Bugis 2018). The extensive microfilming Proyek Pelestarian Naskah has provided access to a vast range of manuscripts in Sulawesi itself (Mukhlis and others 2003). Not least among these new resources is the volume deriving from the Barru seminar, which contains papers on many aspects of La Galigo (Rahman 2003).

Two challenges lie ahead for those concerned with La Galigo studies. The first is to compare various versions of particular episodes with a view to making literary judgements. Is it possible to distinguish between the works of individual composers from the past and identify those of especial merit? Now that so much preliminary philological spade work has been done, can we present and analyse texts which deserve to be read - in translation of course - by those who have no other interest in Bugis history and literature?

The second challenge is to promote a mature understanding of La Galigo as one of the outstanding cultural achievements of Indonesia, alongside the conventional high points from Java and Bali. How can one build on the enthusiasm for La Galigo which is evident on the internet, often with a very poor understanding of the actual cycle itself? The task is to "sell" an accurate account of La Galigo both within Indonesia itself and wherever Indonesian studies are pursued.

While some aspects of this event in Soppeng repeated the formula from the earlier events and not all papers at the seminar took advantage of the new scholarship, developments over the last two decades make it now possible to address these two challenges. The following papers were offered at the seminar. It is hoped to publish a volume based on these later in 2019.

The Place of La Galigo in the archipelago and Beyond

- Marrik Ballen, Asian Collections in Leiden

- Nurhayati Rahman, M.S., La Galigo: merawat keberagaman dan merekat integrasi Nusantara

- Abd. Rasyid Asba, Sawerigading peletak dasar terbentuknya wawasan Nusantara

- Andi Ima Kesuma, Seputar nilai utama dalam naskah La Galigo (telaah pada aspek hubungan internasional, gender, dan nilai lainnya)

- Mu'jizah, Migrasi dan integrasi Bugis

La Galigo In Bugis SOCIETY

- Irfan Mahmud, La Galigo: gerakan literasi dan misi perekat BugisMakassar 
- Pawennari Hijjang, Filosofi sure Galigo pada arsitektur rumah panggung Bugis

- Nurul Ilmi Idrus, "Bugis marriage": between epic La Galigo and contemporary Bugis

- Muhammad Ahlul Amri Buana, La Galigo as legal text? Traces and evolution of adat in Bugis epic cycle

- Makoto Ito, Anak kembar buaya dan upacara kelahiran antara masyarakat Bugis: beberapa catatan buat studi I La Galigo

- Rapi Tang, Mitos Galigo "Mulariulona Batara Guru" episode (saat diturunkannya Batara Guru)

- Muhammad Darwis, Analisis perbandingan strategi kesantunan dalam naskah Lontara Latoa dan Sukku'na Wajo

- Umar Thamrin, Rice and body in Bugis

- Mahmud Tang, Sistem nilai budaya dalam naskah I La Galigo

\section{La Galigo teXTs}

- Campbell Macknight, La Galigo and writing: questions and suggestions

- Andi Muhammad Akhmar, Cerita La Galigo berdasarkan naskah Nb27a

- Sonja Lang, Creating a bilingual dictionary

- Douglas Laskowske, Mensosialisasikan ceritanya "I La Galigo"

- Anil Hukma, La Galigo: dari naskah akademik ke karya kontemporer

The tRavels of La GaLigo

- Faisal Oddang, Ke mana kita membawa La Galigo?

- Kathryn Robinson, Historical traces, memory and identity in the Luwu periphery

- Muhannis, Mitologi Sawerigading di pesisir timur Sulawesi Selatan

- Darmansyah, Tonggak sejarah Mandar I La Galigo

- Muslimin A. R. Effendi, Lawatan Sawerigading ke tanah Bima: penciptaan struktur dan genealogi sejarah yang berpaling

- Norashikin Salleh, La Galigo menerawang ke tanah Melayu

\section{La Galigo In SopPeng}

- Faisal, Maddewata as a performing art of bissu: oral tradition in Bugis Soppeng society

- Noer Jihad Saleh, M.A., Nilai-nilai kearifan lokal tradisi lisan 'massureq' dalam ritual maddojabine

- Muhlis Hadrawi, Peradaban awal masyarakat pada toponimi-toponimi Soppeng yang tergambar di dalam kisah meompalo karellae

- Muhammad Nur dan Akin Duli, Perspektif lingkungan situs-situs kerajaan Soppeng

- Hasanuddin, Tinco di Soppeng: referensi masa hunian wanuwa dan bukti pertanian 


\section{References}

Akhmar, Andi Muhammad 2018, Islamisasi Bugis; kajian sastra atas La Galigo versi bottinna I La Dewata sibawa I Wé Attaweq, Yayasan Pusaka Obor Indonesia, Jakarta.

Fachruddin Ambo Enre 1999, Ritumpanna Wélenrénngé; sebuah episoda sastra Bugis klasik Galigo, École française d'Extrême-Orient/Fakultas Sastra Universitas Indonesia/Yayasan Obor [Naskah dan Dokumen Nusantara Seri 14], Jakarta.

Macknight C.C. 2003, "La Galigo International Seminar and Festival (Barru, South Sulawesi, 15-18 March 2002)," Archipel, vol. 65, pp. 3-6. DOI : https://doi.org/10.3406/ arch.2003.3744

Mukhlis Paeni and others 2003, Katalog induk naskah-naskah Nusantara: Sulawesi Selatan (Arsip Nasional Republik Indonesia, in collaboration with The Ford Foundation, Universitas Hasanuddin), Gadjah Mada University Press, n.p.

Pelras, Christian 2005, "La Galigo, un monument littéraire longtemps méconnu enfin révélé au monde: du mythe identitaire bugis à la production scénique internationale," Ethnologie et Littérature (Collection Eurasie: cahiers de la Société des Études Euro-Asiatiques 14-15), Musée de l'Homme, Paris, pp. 281-352. [republished in Explorations dans l'univers des Bugis: un choix de trente-trois rencontres, Cahiers d'Archipel 39, Paris, 2010, pp. 455-90].

Rahman, Nurhayati and others (eds) 2003, La Galigo: menelusuri jejak warisan sastra dunia, Universitas Hasanuddin/Kapubaten Barru, Makassar.

Rahman, Nurhayati 2006, Cinta, laut, dan kekuasan dalam epos La Galigo: perspektif filologi dan semiotik, La Galigo Press, Makassar.

Robinson, Kathryn 2011, "Sawerigading vs. Sharia: Identities and Political Contestation in Decentralised Indonesia," Asian Journal of Social Science, 39, pp. 219-237.

Salim, Muhammad, Fachruddin Ambo Enre, Nurhayati Rahman, Sirtjo Koolhof and Roger Tol (eds) 2017, La Galigo menurut naskah NBG 188, edisi kedua, 3 vols, Yayasan Pustaka Obor Indonesia, Jakarta.

\section{CAMPBELl MACKNIGHT ${ }^{l}$ AND MUHLIS HADRAWI ${ }^{2}$}

1. College of Asia and the Pacific, Australian National University, Canberra, macknight@ozemail.com.au.

2. Departemen Sastra Daerah, Fakultas Ilmu Budaya, Universitas Hasanuddin, Makassar,muhlisbugis@yahoo.com. 